\title{
The Utilization of Immobilised Substrate/Product in Affinity Chromatography. A Model Study using $\alpha$-Chymotrypsin
}

\author{
PETER BRODELIUS and KLAUS MOSBACH \\ Biochemical Division, Chemical Centre, University of Lund, P.O. Box 740, \\ S-220 07 Lund 7, Sweden
}

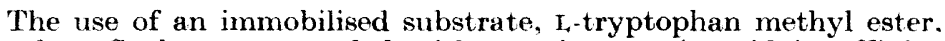
bound to Sepharose extended with $\varepsilon$-aminocaproic acid in affinity chromatography of $\alpha$-chymotrypsin (EC 3.4.4.5) has been studied. The enzyme was significantly retarded on this column material, permitting complete separation from serum albumin and DFP. chymotrypsin. A purification of the crystalline chymotrypsin preparation of about 20 per cent was also achieved.

Separation of chymotrypsin from trypsin (EC 3.4.4.4) was possible using a corresponding column material prepared by coupling $\alpha-N$. (E-aminocaproyl)-L-tryptophan methyl ester to Sepharose.
\end{abstract}

\begin{abstract}
A ffinity chromatography or biospecific adsorption has received increasing attention during the last few years, ${ }^{1,2}$ but two factors hinder the wider use of this technique. One of these factors is the elaborate chemistry often required to immobilise the ligand while the second is that knowledge of specific competitive inhibitors is often lacking. Use of a more general ligand such as the cofactor $\mathrm{NAD}^{+}$or an AMP analogue, e.g. $N^{6}$-(6-aminohexyl)-adenosine 5'-monophosphate, which has affinity for a great number of enzymes, at least partially overcomes the first difficulty ${ }^{3,4}$ Here the specificity associated with affinity chromatography can be preserved by elution of one enzyme at a time.4,5

Since substrate and product are generally established a solution to the second difficulty, which applies particularly to the application of affinity chromatography in the purification of an un-characterised enzyme, may be the coupling of one or the other to a matrix, provided that the binding strength between enzyme and affinity adsorbent is strong enough to bind or at least retard the enzyme of interest. In fact, since binding can be expected to be weak in many instances, this could have the additional advantage that drastic elution methods might not be necessary. With these considerations in mind we started the present investigation by covalently attaching the $\alpha$-chymotrypsin substrate, L-tryptophan methyl ester, to Sepharose extended by a "spacer", $\varepsilon$-aminocaproic acid. The choice of this compound was in part influenced by previous work ${ }^{6}$ on affinity chromatography of this enzyme using the corresponding $\mathrm{D}$-enantiomer, a competitive inhibitor of $\alpha$-chymotrypsin.
\end{abstract}




\section{MATERIALS AND METHODS}

Sepharose 4B was obtained from Pharmacia, Uppsala, Sweden, and DFP-chymotrypsin from Worthington Biochemical Corporation, Freehold, New Jersey, USA. Trypsin (bovine pancreas, type III, 11.000 benzoyl-1-arginine ethyl ester units/mg), $\alpha$-chymotrypsin (bovine pancreas, type II, 46 benzoyl-I,-tyrosine ethyl ester units/mg), bovine serum

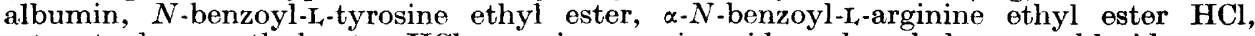
L-tryptophan methyl ester $\mathrm{HCl}, \varepsilon$-aminocaproic acid, and carbobenzoxychloride were purchased from Sigma Chemical Company, St. Louis, Mo., USA. 1-Cyclohexyl-3-(2morpholinoethyl)-carbodiimide metho- $p$-toluene-sulphonate was obtained from Aldrich Chemical Company Inc., Milwaukee, Wis., USA. $N, N^{\prime}$-Dicyclohexylcarbodiimide, benzoyl chloride, and triethylamine were supplied by British Drug House Chemicals Ltd., Poole, England. Palladium on charcoal $(9.7 \%$ ) was purchased from Degussa, Hanau, West Germany. Chymotrypsin activity was measured according to the method described by Hummel ${ }^{7}$ using $N$-benzoyl-I-tyrosine ethyl ester as substrate. Trypsin was assayed with $\alpha-N$-benzoyl-I,arginine ethyl ester as substrate according to the method described by Schwert and Takenaka. ${ }^{8}$ The amount of chymotrypsin was determined spectrophotometrically at $280 \mathrm{~nm}$ by using $E_{280}(1 \%)=20.0$ to relate molar absorptivity to protein concentration. ${ }^{9}$ The affinity material was prepared by two methods. In the first method (A) $\varepsilon$-aminocaproic acid $(1.0 \mathrm{~g})$ was coupled to Sepharose suspension $(10 \mathrm{ml})$ using the cyanogen bromide method, ${ }^{10}$ and then $\mathrm{L}$-tryptophan methyl ester $(250 \mathrm{mg})$ was attached to the terminal carboxyl group of the spacer using 1-cyclohexyl-3-(2-morpholinoethyl)carbodiimide metho-p-toluene sulphonate $(1.0 \mathrm{~g})$. In the second method (B) $\alpha-N-(\varepsilon$ aminocaproyl)-L-tryptophan methyl ester was synthesized through condensation of $N$.

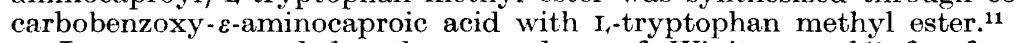

It was prepared by the procedure of Winitz et al. ${ }^{12}$ for formation of peptide bonds by using $N, N^{\prime}$-dicyclohexylcarbodiimide or by the mixed anhydride method described by Vaughan and Osato. ${ }^{.3}$ In either case the carbobenzoxy group was removed by hydrogenolysis with palladium charcoal as catalyst. The synthetic substrate analogue $(200 \mathrm{mg})$ was then coupled to Sepharose suspension $(20 \mathrm{ml})$ by the cyanogen bromide method. Since the ester is insoluble in water, coupling was carried out in a 1:1 mixture of dimethylformamide and $0.1 \mathrm{M} \mathrm{NaHCO}_{3}$.

In preparation (A) the amount of ligand bound was determined either chemically or enzymically. In the chemical procedure the quantity of bound ligand was determined spectrophotometrically by measuring the tryptophan $\left(\varepsilon_{280}=5.56 \times 10^{3}, \mathrm{pH} 7.0\right)^{14}$ liberated when the gel was hydrolysed in $5 \mathrm{M} \mathrm{NaOH}$ for $24 \mathrm{~h}$ at room temperature. This procedure indicated that each $\mathrm{ml}$ of packed gel contained $3 \mu \mathrm{mol}$ of tryptophan methyl ester. In the enzymic method the gel was incubated with an excess of $\alpha$-chymotrypsin and the hydrolysis of tryptophan ester was followed using the $\mathrm{pH}$-stat method with an automatic titrator at $\mathrm{pH}$ 7.8. It was found that $1 \mu \mathrm{mol}$ of ester was hydrolysed per $\mathrm{ml}$ of packed gel. In preparation (B), the bound substrate $(20 \mu \mathrm{mol} / \mathrm{ml}$ of packed gel $)$ was calculated from the difference of tryptophan ester in solution before and after coupling, as determined spectrophotometrically $(280 \mathrm{~nm})$.

\section{RESULTS AND DISCUSSION}

The chromatographic patterns depicted in Fig. $1(a-c)$ were obtained by subjecting various mixtures containing $\alpha$-chymotrypsin to chromatography on the affinity adsorbent (A). The enzyme separated well from a mixture with bovine serum albumin, being significantly retarded, while the albumin (not defatted sample) appeared in the void volume (Fig. 1 (a)). Using such columns, purification of crystalline chymotrypsin preparations was achieved with an approximate increase in specific activity of $20 \%$ (Fig. 1 (b)). Separation of active chymotrypsin from diisopropylfluorophosphate-treated enzyme (DFP-chymotrypsin) could also be effected (Fig. 1 (c)). Here a slight retardation of the inactivated enzyme was observed. Control experiments run with either un- 


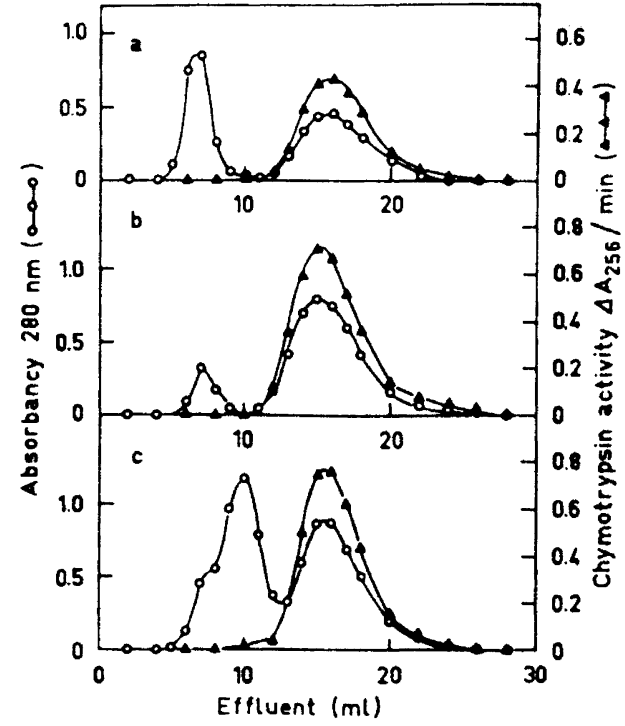

Fig. 1. Chromatography of protein mixtures containing $\alpha$-chymotrypsin on adsorbent (A) packed in a column $(0.9 \times 15$ $\mathrm{cm}$, containing $4.5 \mathrm{ml}$ of packed gel) equilibrated and eluted with $0.05 \mathrm{M}$ Tris$\mathrm{HCl}$ buffer, $\mathrm{pH} 7.8$, at room temperature. $1.0 \mathrm{ml}$ fractions were collected at a rate of $6 \mathrm{ml} / \mathrm{h}$. The following mixtures were applied in $0.2 \mathrm{ml}$ of this buffer: (a) bovine serum albumin $(3.1 \mathrm{mg})$ and $\alpha$-chymotrypsin $(2.0$ $\mathrm{mg}$ ), (b) $\alpha$-chymotrypsin (3.1 $\mathrm{mg}$ ) and (c) DFP-chymotrypsin (2.6mg) and $\alpha$-chymotrypsin (3.2 $\mathrm{mg}$ ).

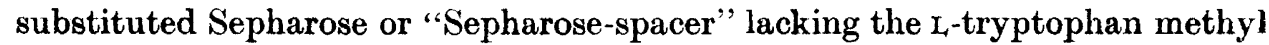
ester gave no retardation of the enzyme in any of the three cases discussed. Thus, immobilisation of the enzyme substrate yields an adsorbent which is sufficiently effective for affinity chromatography, but which, because of the relatively weak binding of the enzyme, requires no special elution procedure. The result of an attempted separation of chymotrypsin from trypsin on a column of adsorbent $(B)$ is shown in Fig. 2. This synthetic material was chosen

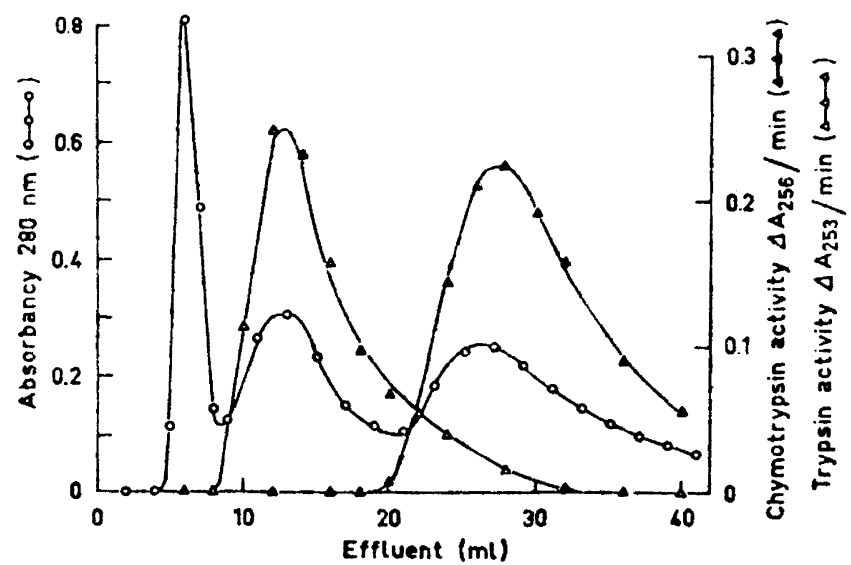

Fig. 2. Chromatography of a mixture of $\alpha$-chymotrypsin $(2.8 \mathrm{mg})$ and trypsin $(3.0 \mathrm{mg})$ on a column of adsorbent (B). The column $(0.9 \times 15 \mathrm{~cm}$, containing $1.5 \mathrm{ml}$ of packed gel) was equilibrated and eluted with $0.05 \mathrm{M}$ Tris-HCl buffer, $\mathrm{pH} 7.8$, at room temperature. $1.0 \mathrm{ml}$ fractions were collected at a rate of $6 \mathrm{ml} / \mathrm{h}$. 
to eliminate any possible contribution to the chromatographic pattern by ionic interaction between free carboxyl groups of unsubstituted $\varepsilon$-aminocaproic acid and the positively charged trypsin (isoelectric point 10.1) ${ }^{15}$ Efficient separation of the two enzymic activities was obtained. The same synthetic preparation (B) was also used in the separation of chymotrypsin from DFPchymotrypsin giving an elution pattern similar to that obtained in Fig. 1 (c).

In an interpretation of the observed affinity chromatographic separations the question of whether these are due to immobilised substrate or product is relevant. This investigation began as a pilot study for possible substrate affinity chromatography. It was found that on carrying out the chromatographic procedure a second time with the same sample of adsorbent the elution profiles changed, showing decreased retardation of the enzyme. Subsequent repetition, however, produced no further changes in the retardation. The elution profiles shown in Fig. $1(a-c)$ were obtained by chromatography on previously used gels. We have shown that under these conditions all the enzymically available bound tryptophan methyl ester was hydrolysed during the first chromatographic use of the gel. This is not surprising in view of the relatively small amount ( $1 \mu \mathrm{mol} / \mathrm{ml}$ of packed gel) of ligand bound. In this context it is interesting to note that the chemically determined bound ligand was about three times as high as the enzymically determined ligand content. This difference is likely to be due to the fact that not all bound tryptophan methyl ester is sterically available for the enzyme. The fact that on repeated runs significant retardation is observed (Fig. 1. $(a-c)$ we ascribe to the interaction of enzyme with the product $N$ - $\varepsilon$-aminocaproyl-L,tryptophan. The literature $K_{\mathrm{i}}$ value for a related compound, $N$-acetyl-L-tryptophan, is $1.75 \times 10^{-2} \mathrm{M}^{16}$ the $N$ - $\varepsilon$-aminocaproyl-L-tryptophan derivative is likely to have a similar or even lower $K_{\mathrm{i}}$ as indicated by a $K_{\mathrm{i}}$ of $0.88 \times 10^{-2} \mathrm{M}$ found for $N$-nicotinyl-1,tryptophan. ${ }^{16}$ Apparently the low affinity of the enzyme for the ligand obtained is sufficient to give the separation observed.

In summary we suggest that in many cases a simple preliminary approach to affinity chromatographic purification, especially of new enzymes, should involve immobilisation of either enzyme substrate or product. Since turnover of substrate may often be complete after one cycle, direct coupling of the product may be the most rational choice, thus utilising the effect of product inhibition in affinity chromatography.

Acknowledgement. The authors wish to acknowledge the skilful help given by Mrs. Margaretha Scott and Dr. Hugh Guilford.

\section{REFERENCES}

1. Cuatrocasas, P. and Anfinsen, C. B. Ann. Rev. Biochem. 40 (1971) 259.

2. Porath, J. and Sundberg, L. The Chemistry of Biosurfaces, Marcel Dekker, Now York 1972, Vol. 2, p. 633.

3. Mosbach, K., Guilford, H., Larsson, P.-O., Ohlsson, R. and Scott, M. Biochem. J. 125 (1971) $20 \mathrm{p}$.

4. Mosbach, K., Guilford, H., Ohlsson, R. and Scott, M. Biochem. J. 127 (1972) 625.

5. Ohlsson, R., Brodelius, P. and Mosbach, K. FEBS Lett. 25 (1972) 234.

6. Cuatrecasas, P., Wilchek, M. and Anfinsen, C. B. Proc. Natl. Acad. Sci. U.S. 61 (1968) 636.

Acta Chem. Scand. 27 (1973) No. 7 
7. Hummel, B. C. W. Can. J. Biochem. Physiol. 37 (1959) 1393.

8. Schwert, G. W. and Takenaka, Y. Biochem. Biophys. Acta 16 (1955) 570.

9. Dixon, G. H. and Neurath, H. J. Biol. Chem. 225 (1957) 1049.

10. Axén, R., Porath, J. and Ernback, S. Nature 214 (1967) 1302.

11. Bergmann, M. and Zervas, L. Ber. 65 (1932) 1192.

12. Winitz, M., Bloch-Frankenthal, L., Izumiya, N., Birnbaum, S. M., Baker, C. G. and Greenstein, J. P. J. Am. Chem. Soc. 78 (1956) 2423.

13. Vaughan, J. R. and Osato, R. L. J. Am. Chem. Soc. 73 (1951) 5553.

14. Sober, H. A., Ed. Handbook of Biochemistry, 2nd Ed., Chemical Rubber Company, Cleveland 1970, p. B.75.

15. Green, N. M. and Neurath, H. The Proteins, Academic, New York 1954, Vol. IIB, p. 1057.

16. Huang, H. T. and Niemann, C. J. Am. Chem. Soc. 73 (1951) 1541.

Received March 6, 1973. 